University of New Hampshire

University of New Hampshire Scholars' Repository

Crimes Against Children Research Center

Research Institutes, Centers and Programs

$12-2009$

\title{
Juveniles Who Commit Sex Offenses Against Minors.
}

\author{
David Finkelhor \\ University of New Hampshire - Main Campus, David.Finkelhor@unh.edu \\ Richard Ormrod \\ University of Northern Colorado \\ Mark Chaffin \\ University of Oklahoma Health Sciences Center
}

Follow this and additional works at: https://scholars.unh.edu/ccrc

Part of the Criminology Commons, and the Psychology Commons

\section{Recommended Citation}

Finkelhor, David; Ormrod, Richard and Chaffin, Mark. Juveniles who commit sex offenses against minors. Juvenile Justice Bulletin - NCJ227763 (1-12pgs). Washington, DC: US Government Printing Office.

This Article is brought to you for free and open access by the Research Institutes, Centers and Programs at University of New Hampshire Scholars' Repository. It has been accepted for inclusion in Crimes Against Children Research Center by an authorized administrator of University of New Hampshire Scholars' Repository. For more information, please contact Scholarly.Communication@unh.edu. 


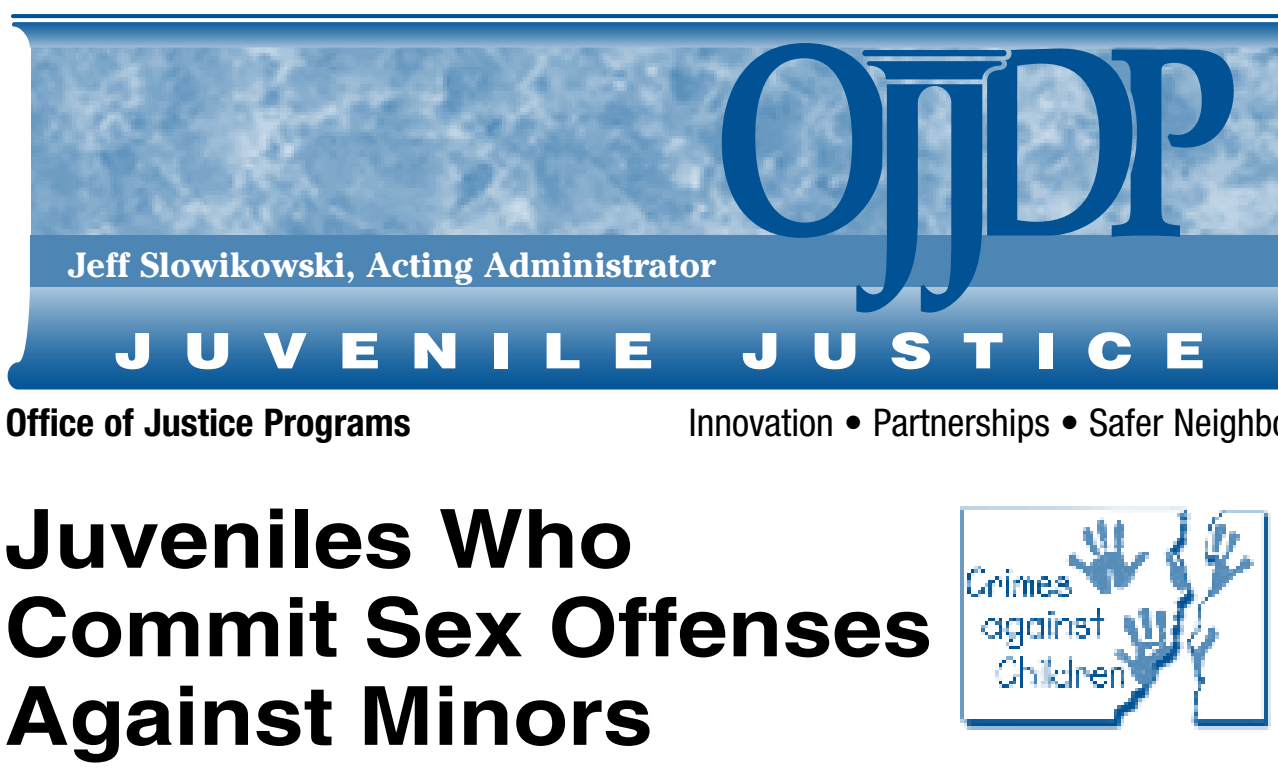

\section{David Finkelhor, Richard Ormrod, and Mark Chaffin}

The Office of Juvenile Justice and Delinquency Prevention (OJJDP) is committed to improving the justice system's response to crimes against children. OJJDP recognizes that children are at increased risk for crime victimization. Not only are children the victims of many of the same crimes that victimize adults, they are subject to other crimes, like child abuse and neglect, that are specific to childhood. The impact of these crimes on young victims can be devastating, and the violent or sexual victimization of children can often lead to an intergenerational cycle of violence and abuse. The purpose of OJJDP's Crimes Against Children Series is to improve and expand the Nation's efforts to better serve child victims by presenting the latest information about child victimization, including analyses of crime victimization statistics, studies of child victims and their special needs, and descriptions of programs and approaches that address these needs.

Although those who commit sex offenses against minors are often described as "pedophiles" or "predators" and thought of as adults, it is important to understand that a substantial portion of these offenses are committed by other minors who do not fit the image of such terms. Interest

\footnotetext{
${ }^{1}$ This Bulletin follows the common convention of referring to these youth as "offenders." However, very few of the youth described with this label in the National Incident-Based Reporting System data are convicted as adults would be. Many were only alleged to have engaged in illegal behavior, and, if subject to justice system action, were adjudicated delinquent rather than convicted of a crime. Thus, the term "juvenile offender" should not imply shared status with convicted adult offenders, legally or otherwise.
}

in youth who commit sexual offenses has grown in recent years, along with specialized treatment and management programs, but relatively little populationbased epidemiological information about the characteristics of this group of offend$\mathrm{ers}^{1}$ and their offenses has been available. The National Incident-Based Reporting System (NIBRS) offers perspective on the characteristics of the juvenile sex offender population coming to the attention of law enforcement.

Key findings from this Bulletin include the following:

- Juveniles account for more than onethird (35.6 percent) of those known to

\section{A Message From OJJDP}

The victimization of youth by adult sex offenders has been an ongoing concern for some time. Although all crimes constitute an assault on civilization, the criminal violation of children is particularly disturbing.

In recent years, there has been increased public interest in the incidence of sexual victimization of youth by other youth. This should not be surprising considering that youth constitute more than one in four sex offenders and that juveniles perpetrate more than one in three sex offenses against other youth.

Research on juvenile sex offenders goes back more than half a century; however, little information about these young offenders and their offenses exists.

This Bulletin draws on data from the Federal Bureau of Investigation's National Incident-Based Reporting System to provide population-based epidemiological information on juvenile sex offending.

It is OJJDP's hope that the findings reported in this Bulletin and their implications will help inform the policy and practice of those committed to addressing the sexual victimization of youth and strengthening its prevention and deterrence-considerations that are critical to success. Their efforts to protect youth from victimization, or from becoming victimizers themselves, have our support and commendation. 
police to have committed sex offenses against minors.

- Juveniles who commit sex offenses against other children are more likely than adult sex offenders to offend in groups and at schools and to have more male victims and younger victims

- The number of youth coming to the attention of police for sex offenses increases sharply at age 12 and plateaus after age 14. Early adolescence is the peak age for offenses against younger children. Offenses against teenagers surge during mid to late adolescence, while offenses against victims under age 12 decline.

- A small number of juvenile offenders1 out of 8 -are younger than age 12 .

- Females constitute 7 percent of juveniles who commit sex offenses.

- Females are found more frequently among younger youth than older youth who commit sex offenses. This group's offenses involve more multiple-victim and multiple-perpetrator episodes, and they are more likely to have victims who are family members or males.

- Jurisdictions vary enormously in their concentration of reported juvenile sex offenders, far more so than they vary in their concentration of adult sex offenders.

\section{Background}

Research on juvenile sex offenders goes back more than 50 years, but most of what is known comes from a surge of interest in the subject that began in the mid-1980s (Chaffin, Letourneau, and Silovsky, 2002), culled primarily from populations of youth in sex offender treatment programs. Juvenile sex offender treatment programs saw a 40-fold increase between 1982 and 1992 (Knopp, Freeman-Longo, and Stevenson, 1992). Accordingly, the number of published research articles on juvenile sex offenders increased from a handful prior to the mid-1980s to more than 200 studies currently. Dissemination of information about these offenders has included federally funded efforts from sources such as the Center for Sex Offender Management and the National Center on the Sexual Behavior of Youth. Professional societies such as the Association for the Treatment of Sexual Abusers have also published policy and practice guidelines.
Most of the clinical sample studies on which current knowledge is based have focused on the clinical characteristics of offenders, treatment issues, risk predictors, and recidivism rates (Becker, 1998). The clinical literature has generally considered teenage and preteen offenders as different offender types: teenage sex offenders are predominately male (more than 90 percent), whereas a significant number of preteen offenders are female (Silovsky and Niec, 2002). Most offenses described in the clinical literature involve teenage offenders acting alone with young children as victims. Many specialized intervention systems are designed with this type of behavior in mind.

Early thinking about juvenile sex offenders was based on what was known about adult child molesters, particularly adult pedophiles, given findings that a significant portion of them began their offending during adolescence. However, current clinical typologies and models emphasize that this retrospective logic has obscured

\section{The National Incident-Based Reporting System (NIBRS)}

The U.S. Department of Justice is replacing its long-established Uniform Crime Reports (UCR) system with a more comprehensive National Incident-Based Reporting System (NIBRS). Whereas UCR monitors only a limited number of index crimes and gathers few details on each crime event (except in the case of homicide), NIBRS collects a wide range of information on victims, offenders, and circumstances for a greater variety of offenses. Offenses tracked in NIBRS include violent crimes (e.g., homicide, assault, rape, robbery), property crimes (e.g., theft, arson, vandalism, fraud, and embezzlement), and crimes against society (e.g., drug offenses, gambling, prostitution). Moreover, NIBRS collects information on multiple victims, multiple offenders, and multiple crimes that may be part of the same episode.

Under the new system, as under the old, local law enforcement personnel compile information on crimes coming to their attention and the information is then aggregated at State and national levels. For a crime to count in the system, law enforcement simply needs to report and investigate the crime. The incident does not need to be cleared, nor must an arrest be made, though unfounded reports are deleted.

NIBRS holds great promise, but it is still far from a national system. The Federal Bureau of Investigation (FBI) began implementing the system in 1988, and State and local agency participation is voluntary and incremental. By 1995, jurisdictions in 9 States had agencies contributing data; by 1997, the number was 12; and by 2004, jurisdictions in 29 States submitted reports, providing coverage for 20 percent of the Nation's population and 16 percent of its crime. At the beginning of 2004, only 7 States (Delaware, Idaho, lowa, South Carolina, Tennessee, Virginia, and West Virginia) had participation from all local jurisdictions, and only 5 cities with a population greater than 500,000 (Columbus, OH; El Paso, TX; Memphis, TN; Nashville, TN; and Milwaukee, WI) were reporting. The crime experiences of large urban areas are thus particularly underrepresented. The system, therefore, is not yet nationally representative, nor do its data represent national trends or national statistics. Nevertheless, the system is assembling large amounts of crime information and providing rich detail about juvenile offending and victimization that was previously unavailable. The patterns and associations these data reveal are real and represent the experiences of a large number of youth. For 2004, the 29 participating States* reported more than 4,037,000 crime incidents, with at least 14,000 involving an identified juvenile sex offender. As more jurisdictions join the system, new patterns may emerge.

More information about NIBRS data collection can be found at these Web sites:

(1) www.fbi.gov/ucr/ucr.htm\#cius

(2) www.ojp.usdoj.gov/bjs/nibrs.htm

(3) www.jrsa.org/ibrrc

* In 2004, participating States included Arizona, Arkansas, Colorado, Connecticut, Delaware, Georgia, Idaho, Iowa, Kansas, Kentucky, Louisiana, Maine, Massachusetts, Michigan, Nebraska, New Hampshire, North Dakota, Ohio, Oregon, Rhode Island, South Carolina, South Dakota, Tennessee, Texas, Utah, Vermont, Virginia, West Virginia, and Wisconsin. 
important motivational, behavioral, and prognostic differences between juvenile sex offenders and adult sex offenders and has overestimated the role of deviant sexual preferences in juvenile sex crimes. More recent models emphasize the diversity of juvenile sex offenders, their favorable prognosis suggested by low sex-offenserecidivism rates, and the commonalities between juvenile sex offending and other juvenile delinquency (Letourneau and Miner, 2005).

Clinical studies also underscore a diversity of behaviors, characteristics, and future risk. For example, the sexual behaviors that bring youth into clinical settings can include events as diverse as sharing pornography with younger children, fondling a child over the clothes, grabbing peers in a sexual way at school, date rape, gang rape, or performing oral, vaginal, or anal sex on a much younger child. Offenses can involve a single event, a few isolated events, or a large number of events with multiple victims. Juvenile sex offenders come from a variety of social and family backgrounds and can either be well functioning or have multiple problems. A number have experienced a high accumulated burden of adversity, including maltreatment or exposure to violence; others have not. In some cases, a history of childhood sexual abuse appears to contribute to later juvenile sex offending (Lambie et al., 2002), but most sexual abuse victims do not become sex offenders in adolescence or adulthood (Widom and Ames, 1994). Among preteen children with sexual behavior problems, a history of sexual abuse is particularly prevalent.

In addition to a diversity of backgrounds, diversity in motivation is evident. Some juvenile sex offenders appear primarily motivated by sexual curiosity. Others have longstanding patterns of violating the rights of others. Some offenses occur in conjunction with serious mental health problems. Some of the offending behavior is compulsive, but it more often appears impulsive or reflects poor judgment (Becker, 1998; Center for Sex Offender Management, 1999; Chaffin, 2005; Hunter et al., 2003).

Similarly, clinical data point to variability in risk for future sex offending as an adult. Multiple short- and long-term clinical followup studies of juvenile sex offenders consistently demonstrate that a large majority (about 85-95 percent) of sex-offending youth have no arrests or reports for future sex crimes. When previously sex-offending

\section{Using NIBRS Data To Investigate Juvenile Sex Offenders}

The information presented in this Bulletin about juvenile sex offenders is based on data collected by the National Incident-Based Reporting System (NIBRS) for 2004 (see discussion of the National Incident-Based Reporting System on page 2). At present, NIBRS is the only available source of geographically diverse and uniformly collected crime data that provides detailed descriptions of juvenile sex offenders, their victims, and the crime incidents they initiate. The offenders and incidents recorded by NIBRS represent only those that come to the attention of police.

The basic unit of data organization in NIBRS is the crime incident. An incident is defined as "one or more offenses committed by the same offender, or group of offenders acting in concert, at the same time and place" (U.S. Department of Justice, Federal Bureau of Investigation, 2004:191). Thus, a single sex offense incident can be characterized by additional offenses beyond a sex offense or even multiple sex offenses, by multiple offenders, and by multiple victims. Most sex offense incidents, however, are not so complex.

For this Bulletin, the basic unit of measure is the individual sex offender, although NIBRS links each offender to broader incident characteristics, such as the number of offenders present, victim age and identity, incident location, and time of day. Although juveniles sometimes commit sex crimes against adults, the majority (96.2 percent) of those known to police target other juveniles. These offenders, juveniles who commit sex offenses against minors, are of particular interest to this analysis. Unless stated otherwise in this Bulletin, "sex offender" (both juvenile and adult) refers to those committing sex offenses against minors.

For purposes of analysis, juvenile victims are defined as persons younger than 18; juvenile offenders are defined as persons of ages 6 through 17. (Although NIBRS records include a small number of children younger than 6 years of age, the notion of very young children committing sex crimes is problematic, so these children were excluded from this analysis.) An adult is defined as a person 18 years of age or older. It is also important to note that the offender ages recorded in NIBRS reflect the ages of the youth at the time the incidents are reported, not the ages at the time the incidents occurred, which are different in 19 percent of cases.

This Bulletin makes some comparisons between an individual offender and an individual victim (e.g., age difference, gender similarity or difference).

[continued on page 4]

youth do have future arrests, they are far more likely to be for nonsexual crimes such as property or drug offenses than for sex crimes (Alexander, 1999; Caldwell, 2002; Reitzel and Carbonell, 2007). These empirical findings contrast with popular thought and widely publicized anecdotal cases that disproportionately portray incidences of sex crime recidivism. Nevertheless, a small number of sex-offending youth are at elevated risk to progress to adult sex offenses. To identify those who are more likely to progress to future offending, researchers have developed actuarial risk assessment tools that have demonstrated some predictive validity; efforts to refine these tools are underway (Parks and Bard, 2006; Righthand et al., 2005; Worling, 2004).

Unfortunately, research on juvenile sex offenders beyond clinical populations has been more limited. Few studies have surveyed representative youth populations to ascertain population-based rates of juvenile offending (e.g., Elliott, Huizinga, and Menard, 1989). Juvenile sex offenses reported to authorities yield official crime report data, but these data typically contain limited information about the nature of the incidents involved. As more detailed crime report data become available, and as researchers study these data in conjunction with clinical sample data, the information gained will assist prevention and intervention planning substantially.

\section{Juvenile and Adult Sex Offenders Known to Police}

Juvenile sex offenders comprise more than one-quarter (25.8 percent) of all sex offenders and more than one-third (35.6 percent) of sex offenders against juvenile victims (the group that is the focus of this Bulletin). As a percentage of all juvenile offenders, they do not constitute a large 


\section{Using NIBRS Data To Investigate Juvenile Sex Offenders (continued)}

For offenders in incidents with multiple victims (12.8 percent of juvenile offenders), this Bulletin uses the youngest victim for these comparisons.

NIBRS data identify a number of specific sex offenses and classify them as either forcible (rape, sodomy, sexual assault with an object, fondling) or nonforcible (incest, statutory rape) sex offenses. It defines a forcible sex offense as "any sexual act directed against another person, forcibly and/or against that person's will; or not forcibly or against the person's will where the victim is incapable of giving consent" (U.S. Department of Justice, Federal Bureau of Investigation, 2004:191). A person may be incapable of giving consent because of temporary or permanent mental or physical incapacity or because of youth. Furthermore, NIBRS guidelines direct that "the ability of the victim to give consent must be a professional determination by the law enforcement agency" (U.S. Department of Justice, Federal Bureau of Investigation, 2004:191). A nonforcible sex offense is defined as "unlawful, nonforcible sexual intercourse" (U.S. Department of Justice, Federal Bureau of Investigation, 2004:192).

Although NIBRS attempts to standardize crime definitions, individual police officers and jurisdictions may categorize similar episodes in very different ways for NIBRS purposes, so the distinctions among various sex offense categories may be less clear than the names might imply. Although statutes do describe illegal sexual behavior that could easily be classified as nonforcible (e.g., showing pornography or making sexual suggestions to a child) and other behaviors that are clearly forcible (e.g., rape), how law enforcement might categorize less straightforward cases (e.g., physically noncoercive fondling between youth of widely disparate ages) may be less reliable. For this Bulletin, "sex offender" refers to a person who has committed either a forcible or nonforcible sex offense, although the majority of juvenile sex offenders (90.5 percent) reported in NIBRS committed a forcible sex offense.

\section{Figure 1: Age Distribution of Juvenile Sex Offenders, by Victim Age}

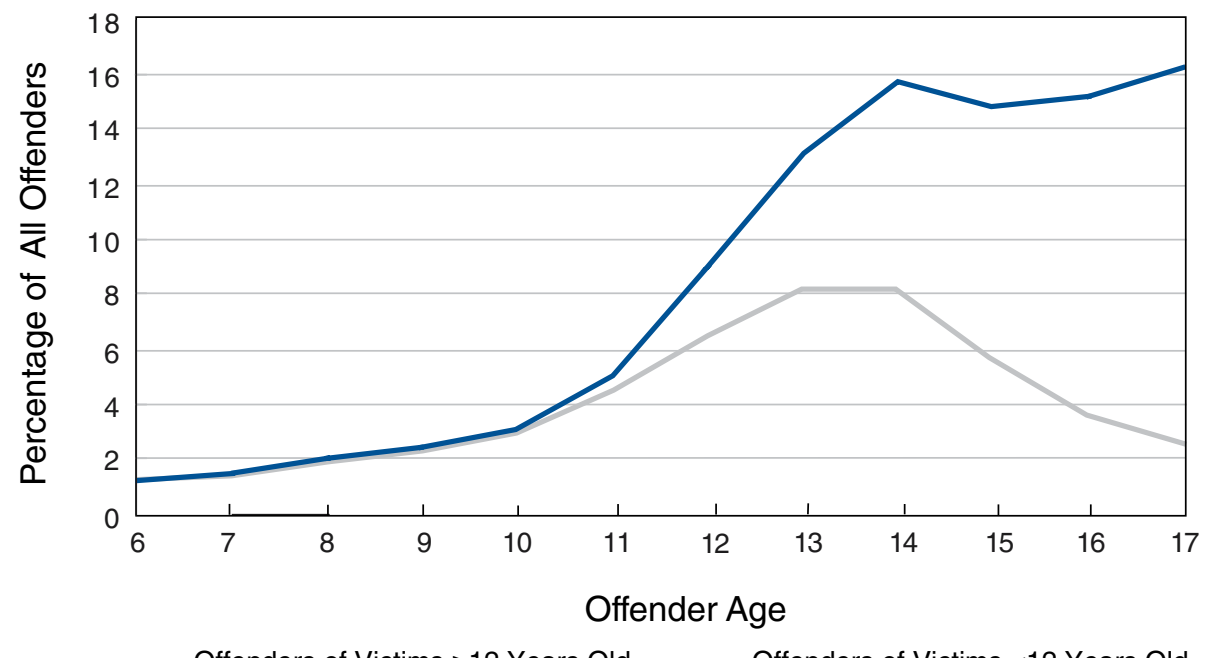

Note: $N=13,471$ juvenile offenders.

Source: U.S. Department of Justice, Federal Bureau of Investigation, National Incident-Based Reporting System, 2004. group-juvenile sex offenders account for only 3.1 percent of all juvenile offenders and 7.4 percent of all violent juvenile offenders. If other jurisdictions in the country were assumed to be the same as the NIBRS jurisdictions, one would extrapolate approximately 89,000 juvenile sex offenders known to police throughout the United States in 2004.

Known juvenile offenders who commit sex offenses against minors span a variety of ages. Five percent are younger than 9 years, and 16 percent are younger than 12 years (figure 1). The rate rises sharply around age 12 and plateaus after age 14 . As a proportion of the total, 38 percent are between ages 12 and 14, and 46 percent are between ages 15 and 17 . The vast majority (93 percent) are male.

Juveniles who commit sex offenses against minors are different from adults who commit sex offenses against minors on a number of crucial dimensions captured by NIBRS (table 1, page 5). Juveniles are more likely to offend in groups (24 percent with one or more co-offenders versus 14 percent for adults). They are somewhat more likely to offend against acquaintances (63 percent versus 55 percent). Their most serious offense is less likely to be rape (24 percent versus 31 percent) and more likely to be sodomy (13 percent versus 7 percent) or fondling (49 percent versus 42 percent). They are more likely to have a male victim (25 percent versus 13 percent).

Sex offenses committed by juveniles very often occur in the home, although somewhat less often than their adult counterparts (69 percent versus 80 percent) but are more likely to occur in a school (12 percent versus 2 percent). Their offenses occur somewhat more in the afternoon (43 percent versus 37 percent for adults) than in the evening ( 25 percent versus 28 percent) or at night (5 percent versus 9 percent).

Juvenile sex offenders are also much more likely than adult sex offenders to target young children as their victims. The proportion of victims younger than the age of 12 is 59 percent for juvenile sex offenders, compared with 39 percent for adult sex offenders. Figure 2 (page 6) shows how adult sex offenders concentrate their offenses against victims age 13 and older. In contrast, the age range of victims of juvenile sex offenders is more dispersed, and 16- 
and 17-year-old victims actually represent a surprisingly small proportion. Juvenile sex offenders are less likely to target other juveniles who are older than they are. Figure 2 also shows that children younger than age 12 have about an equal likelihood of being victimized by juvenile and adult sex offenders, but adult offenders predominate among those who victimize teens.

Juvenile sex offenders more commonly target other juveniles who are somewhat younger than they are, signaling a clear relationship between the age of juvenile sex offenders and the age of their victims (figure 3 , page 6 ). When juvenile sex offenders are themselves 6 to 9 years old, the mean age of their victims is between 5 and 7 . When juvenile sex offenders are age 15 to 17 , the mean age of their victims is between 11 and 13 . However, when victims are younger than age 12, there is a marked peak for offending by 13- to 14-year-olds, and then a dramatic decline in the targeting of these young victims by youth age 15 and older (figure 1). Youth age 15 and

Table 1: Characteristics of Juveniles and Adults Who Commit Sex Offenses Against Minors

\begin{tabular}{|c|c|c|}
\hline \multirow[b]{2}{*}{ Characteristic } & \multicolumn{2}{|c|}{ Sex Offenders (\%) } \\
\hline & $\begin{array}{c}\text { Juvenile } \\
(N=13,471)\end{array}$ & $\begin{array}{c}\text { Adult } \\
(N=24,344)\end{array}$ \\
\hline Multiple offenders in incident & 23.9 & 13.5 \\
\hline Two offenders & 14.4 & 9.1 \\
\hline Three or more offenders & 9.5 & 4.4 \\
\hline \multicolumn{3}{|l|}{ Victim identity (youngest victim) } \\
\hline Family & 25.0 & 31.9 \\
\hline Acquaintance & 63.2 & 54.8 \\
\hline Stranger & 2.5 & 4.4 \\
\hline Victim was also offender & 0.8 & 0.0 \\
\hline Unknown & 8.4 & 9.0 \\
\hline \multicolumn{3}{|l|}{ Sex offense (most serious) } \\
\hline Rape & 24.0 & 30.6 \\
\hline Sodomy & 12.5 & 6.5 \\
\hline Sex assault with object & 4.7 & 4.4 \\
\hline Fondling & 49.4 & 42.1 \\
\hline Nonforcible sex offense & 9.5 & 16.3 \\
\hline Female offender & 7.3 & 5.4 \\
\hline \multicolumn{3}{|l|}{ Victim gender } \\
\hline Any female victim in incident & 78.8 & 88.2 \\
\hline Any male victim in incident & 24.7 & 13.4 \\
\hline \multicolumn{3}{|l|}{ Incident location } \\
\hline Residence/home & 68.8 & 79.6 \\
\hline School/college & 11.9 & 1.6 \\
\hline Store/building & 3.8 & 4.8 \\
\hline Outside & 7.1 & 6.7 \\
\hline Other/unknown & 8.3 & 7.3 \\
\hline \multicolumn{3}{|l|}{ Incident time of day } \\
\hline Morning ( 6 a.m. to 12 p.m.) & 26.7 & 25.1 \\
\hline Afternoon (12 p.m. to 6 p.m.) & 43.0 & 37.3 \\
\hline Evening ( 6 p.m. to 12 a.m.) & 25.2 & 28.3 \\
\hline Night (12 a.m. to 6 a.m.) & 5.2 & 9.2 \\
\hline Arrest in incident & 30.5 & 34.1 \\
\hline
\end{tabular}

Source: U.S. Department of Justice, Federal Bureau of Investigation, National Incident-Based Reporting System, 2004.

older primarily target postpubescent victims.

This relationship between offender age and victim age also varies by victim gender, as shown in figures 4 (page 8) and 5 (page 10). When the victims are boys, a majority are younger than age 12 , and there is also a marked peak reflecting 12- to 14-year-old sex offenders targeting 4 - to 7 -year-old boys. When the victims are girls, by contrast, there is a greater link between the rise in age of the offender and the victim, and the peak is among 15- to 17-year-olds targeting 13- to 15-yearold girls. This suggests that when teen offenders target boys, they tend to focus on much younger and sexually immature boys rather than their peers, whereas when older teen offenders target girls, they tend to focus more on sexually mature females. This finding may stem from the fact that juvenile offenders may find it easier to dominate girls and younger boys than to dominate older boys. However, it could also be that older male victims of teenage offenders are particularly reluctant to report their victimizations to police compared with teenage female victims.

\section{Younger Juvenile Sex Offenders}

Although most juvenile sex offenders are teenagers, about 16 percent of those who come to police attention are younger than age 12. This group has been of particular interest to clinicians, educators, and public safety officials, who have been reluctant to regard them in the same delinquency-oriented framework that has applied to older offenders. Professionals commonly use other terms, such as "children with sexual behavior problems," to describe this group. What proportion of these children come to police attention is unclear because these cases may be handled exclusively within other systems, such as the child protection system or schools. However, the group of younger juvenile offenders who come to police attention does manifest certain characteristics that differentiate them from older offenders (table 2, page 7).

Offenders younger than age 12 are somewhat more likely than offenders age 12 or older to be female and to offend in multiple offender and multiple victim episodes. Younger offenders are also somewhat more likely than older offenders to 
offend against family members and in a residential environment. Younger offenders are more likely than older offenders to target male victims (37 percent versus
20 percent) and younger victims closer to their own age. Their most serious offense is more likely to be fondling and less likely to be rape. Police are considerably less

\section{Figure 2: Age Distribution of Juvenile Sex Victims, by Offender Age}



Note: $N=37,815$ juvenile victims, 13,471 (36 percent) with juvenile offenders and 24,344 (64 percent) with adult offenders. For offenders with multiple victims, age of youngest victim is shown.

Source: U.S. Department of Justice, Federal Bureau of Investigation, National Incident-Based Reporting System, 2004.

\section{Figure 3: Juvenile Sex Victim Age, by Juvenile Offender Age}

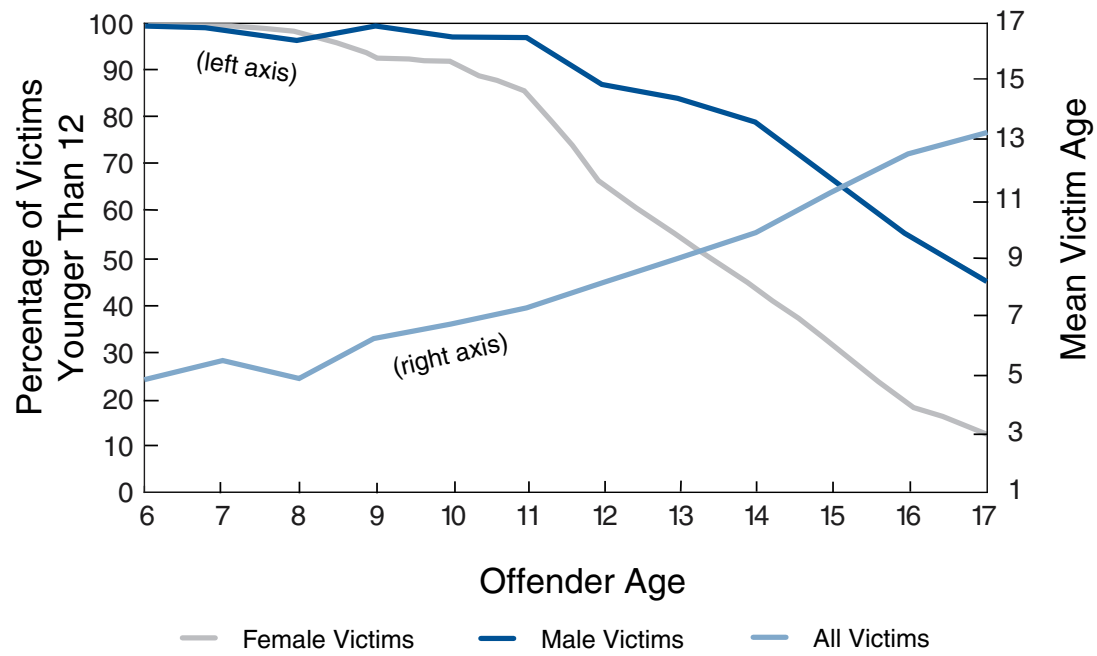

Note: $N=13,471$ juvenile offenders. For offenders with multiple victims, age of youngest victim is shown.

Source: U.S. Department of Justice, Federal Bureau of Investigation, National Incident-Based Reporting System, 2004.

likely to arrest younger offenders than older offenders in the wake of a report (17 percent versus 33 percent).

\section{Female Juvenile Sex Offenders}

Female juvenile sex offenders are another group who have attracted a particular interest among clinicians and law enforcement officials. They constitute only a small proportion (7 percent) of all juvenile sex offenders in the NIBRS database, but they have several features that distinguish them from male juvenile sex offenders (table 3, page 9).

Female offenders are younger than their male counterparts. Of the female offenders, 31 percent were younger than 12 , compared with only 14 percent of male offenders. Female offenders were considerably more likely than male offenders to offend in conjunction with others (36 percent versus 23 percent) and in conjunction with adults (13 percent versus 5 percent). They were also more likely to be involved in incidents with multiple victims than were male offenders (23 percent versus 12 percent) and to be considered by investigators to be victims at the same time they were offending.

Female offenders are somewhat more likely to offend in a residence or home and less likely to offend at a school. They were more likely than male offenders to have male victims (37 percent versus 21 percent) and victims younger than age 11 (60 percent versus 43 percent).

\section{Reporting Juvenile Sex Offenses}

Concern about juvenile sex offenders is a relatively recent phenomenon. Some communities have mobilized quite energetically in recent years to identify and intervene with such youth, conducting extensive training among law enforcement, child protection staff, and educators and establishing specialized treatment programs. In other communities, however, concern about the problem has been slow to develop. Thus, the spectrum of community activity surrounding juvenile sex offenders ranges from very slight in some jurisdictions to exaggerated or disproportionate in other jurisdictions.

This variability in community response is reflected in the data from NIBRS jurisdictions, which differ considerably in the 
concentration of juvenile sex offenders in their caseloads. Some jurisdictions may have unusually high concentrations of juvenile sex offenders. In NIBRS jurisdictions with populations greater than 5,000 (classified as "city" type jurisdictions) and that have at least 10 juvenile violent offenders, juvenile sex offenders constitute 6 percent of the total number of juvenile violent offenders overall. However, a considerable number of jurisdictions have particularly high concentrations of

Table 2: Characteristics of Juvenile Sex Offenders Who Victimize Minors, by Age of Offender

Juvenile Sex Offenders (\%)

\begin{tabular}{|c|c|c|}
\hline \multirow[b]{2}{*}{ Characteristic } & \multicolumn{2}{|c|}{ Juvenile Sex Offenders (\%) } \\
\hline & $\begin{array}{c}\text { Younger (age }<12 \text { years) } \\
(N=2,104)\end{array}$ & $\begin{array}{l}\text { Older (age } \geq 12 \text { years) } \\
\quad(N=11,367)\end{array}$ \\
\hline Multiple offenders in incident & 29.0 & 23.0 \\
\hline Adult offender in incident & 2.6 & 5.7 \\
\hline Female offender & 14.6 & 5.9 \\
\hline Multiple victims in incident & 16.0 & 12.1 \\
\hline \multicolumn{3}{|l|}{ Victim identity (youngest victim) } \\
\hline Family & 31.6 & 23.8 \\
\hline Acquaintance & 56.0 & 64.5 \\
\hline Stranger & 1.6 & 2.7 \\
\hline Victim is also offender & 1.0 & 0.8 \\
\hline Unknown & 9.7 & 8.2 \\
\hline \multicolumn{3}{|l|}{ Incident location } \\
\hline Residence/home & 73.0 & 68.1 \\
\hline School/college & 10.8 & 12.1 \\
\hline Store/building & 2.9 & 4.0 \\
\hline Outside & 5.0 & 7.4 \\
\hline Other/unknown & 8.2 & 8.3 \\
\hline \multicolumn{3}{|l|}{ Victim gender (youngest victim) } \\
\hline Male & 36.6 & 19.9 \\
\hline Female & 63.4 & 80.1 \\
\hline \multicolumn{3}{|l|}{ Age of youngest victim (years) } \\
\hline $0-6$ & 57.1 & 21.0 \\
\hline $7-10$ & 31.2 & 15.5 \\
\hline $11-14$ & 10.9 & 43.2 \\
\hline $15-17$ & 0.8 & 20.2 \\
\hline \multicolumn{3}{|l|}{ Sex offense (most serious) } \\
\hline Rape & 11.0 & 26.4 \\
\hline Sodomy & 15.4 & 11.9 \\
\hline Sex assault with object & 7.2 & 4.2 \\
\hline Fondling & 61.3 & 47.2 \\
\hline Nonforcible sex offense & 5.1 & 10.5 \\
\hline \multicolumn{3}{|l|}{ Injury in incident } \\
\hline None & 88.8 & 86.9 \\
\hline Minor & 9.6 & 10.6 \\
\hline Major & 1.6 & 2.5 \\
\hline \multicolumn{3}{|l|}{ Incident time of day } \\
\hline Morning (6 a.m. to 12 p.m.) & 28.9 & 26.3 \\
\hline Afternoon (12 p.m. to 6 p.m.) & 45.6 & 42.5 \\
\hline Evening (6 p.m. to 12 a.m.) & 22.7 & 25.7 \\
\hline Night (12 a.m. to 6 a.m.) & 2.8 & 5.6 \\
\hline Arrest in incident & 16.5 & 32.9 \\
\hline
\end{tabular}

Source: U.S. Department of Justice, Federal Bureau of Investigation, National Incident-Based Reporting System, 2004.

juvenile sex offenders. For example, of the identified NIBRS jurisdictions, 8 percent have concentrations of juvenile sex offenders that are three times that of the median jurisdiction (i.e., more than 25 percent of the jurisdiction's juvenile violent offenders are sex offenders). In contrast, just 4 percent of the identified NIBRS jurisdictions have concentrations of adult sex offenders that are triple the rate for the median jurisdiction.

There is also evidence of a tendency in other jurisdictions for juvenile sex offenders to represent a disproportionately small proportion of all juvenile violent offenders. In 29 percent of the identified NIBRS jurisdictions, the concentration of juvenile sex offenders equals half the median concentration (a low proportion) for the group of NIBRS jurisdictions identified above. In contrast, only 19 percent of the identified NIBRS jurisdictions have a similarly low concentration of adult sex offenders. That is, in contrast to the situation with adult sex offender concentrations, more jurisdictions have either a very high concentration of juvenile sex offenders or a concentration that is particularly low, reflecting, perhaps, contrasting levels of interest in this offender group. Table 4 (page 10) suggests that large jurisdictions are particularly likely to have low concentrations of juvenile sex offenders among their juvenile violent offender population. It is also possible that these jurisdictions have higher rates of violent nonsexual juvenile offending, which lowers the relative percentage of juvenile sex offenders.

\section{Implications}

These findings suggest a number of implications for policy and practice. First, the statistics clearly highlight the fact that juveniles continue to constitute a substantial proportion-more than one-third-of those who commit sexual offenses against minors. This proportion is comparable to that found in reports from other samples and from earlier periods (Davis and Leitenberg, 1987; Snyder and Sickmund, 1999). Thus, any effort to prevent or intervene in sexual assault and child molestation must address the risk that juvenile sex offenders pose. Prevention and deterrence messages should be directed to youthful audiences in schools, youth organizations, on the Internet, on youth-oriented media, and even in families. Victimization prevention messages delivered to potential victims and their caregivers should be broadened to include information about 


\section{Figure 4: Juvenile Sex Offenders Versus Male Juvenile Victims}

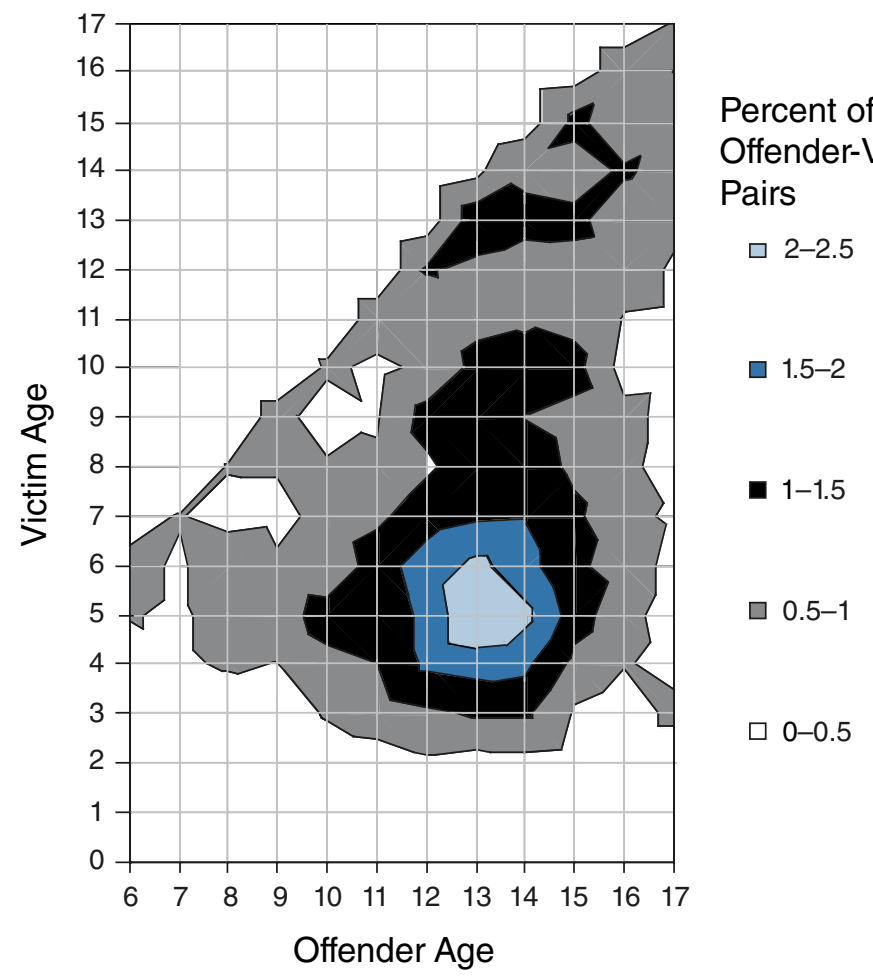

Source: U.S. Department of Justice, Federal Bureau of Investigation, National Incident-Based Reporting System, 2004.

the risk of sexual abuse not only from adults but also from juveniles.

In addition, perpetration prevention programs that have been targeted primarily toward at-risk adult populations need to begin earlier (Ryan, 1997), with youth younger than age 12 , the age at which these findings suggest an escalation in offending occurs. Given the sharp increase in sex offense rates at this age, prevention messages delivered to boys prior to early adolescence may be essential to consider. The prevention messages for these preteens may need to focus on their risk for victimizing much younger children (ages 4-7). Families and institutions may need to stay vigilant about contexts that involve pairings of young teenage boys with much younger children. This is not to suggest that all young teenage boys pose a high risk for molesting children. Very few juveniles of any age commit sex offenses. Rather, it is simply that the risk of offending against children during this developmental period appears to be relatively higher than at other ages. Therefore, some increased vigilance may be appropriate. This might include taking additional care to check references when considering young teenage babysitters and exercising closer supervision or monitoring of interactions.

Different preventive priorities seem important for older teenagers. Given the older age profile for victims of older teenagers, prevention messages may need to shift as youth enter middle adolescence. Prevention messages for these older teenagers may be better focused on the dynamics of date and teenager-on-teenager rape. The Centers for Disease Control and Prevention (CDC) have developed a multilevel public health primary-perpetration prevention model that includes suggested prevention activities at the individual, relationship, community, and societal levels (Centers for Disease Control and Prevention, 2004), including a focus on juvenile perpetration prevention.

To ensure adequate intervention with the large proportion of juveniles among the sex offender population, police, prosecutors, and probation and parole officials need adequate training and resources to respond effectively and sensitively to juvenile sex offenders. They must conduct investigations and manage juvenile offenders in a way that best prevents reoffending. Fortunately, several intervention strategies have proven effective in reducing recidivism among teenage sex offenders, and communities should acquaint themselves with these approaches (Borduin and Schaeffer, 2001; Reitzel and Carbonell, 2007; Letourneau et al., 2009). Good results have also been reported across a number of short-term interventions with juvenile offenders younger than age 12 (Chaffin et al., 2008). Researchers found that one brief treatment for preteens reduced the risk of future sex offenses to levels comparable with those of children who had no history of inappropriate sexual behavior (Carpentier, Silovsky, and Chaffin, 2006).

Analysis of the study data also highlights certain features of juvenile sex offenders that policymakers should take into account. First, the findings emphasize the diversity among juveniles who commit sex offenses. This population clearly includes older and younger youth, males and females, those who offend against much younger children, those who offend against peers, those who offend alone, and those who offend in groups, among other diverse characteristics. This diversity indicates the need to avoid stereotypes about juvenile sex offenders and to develop prevention and response strategies that can accommodate many of these various types of youth and offenses. Similarly, public policies must reflect the diversity among juvenile sex offenders by adopting more nuanced and flexible procedures rather than broad mandates.

The analyses reiterate many findings from the clinical sample literature, notably, that individuals known to the victim, including family members, are those who most often commit sexual assaults; that around 90 percent of known teen offenders are male; and that preteens with sexual behavior problems include a higher percentage of girls. Given the natural reluctance to consider family members and other trusted persons among those who may pose a danger, these findings underscore the need for information about prevention to emphasize that risk can include family members or other well-known persons.

The findings show that young boys are highly vulnerable to offenses by other 
juveniles. Parents, schools, or prevention programs that have focused on limiting or supervising contact between female children and older male juveniles or adults must revise their messages to include examples involving young male victims, and perhaps even female perpetrators. Because boys younger than 12 are particularly at risk, it is important to give them prevention information that addresses

Table 3: Characteristics of Juvenile Sex Offenders Who Victimize Minors, by Gender of Offender

\begin{tabular}{|c|c|c|}
\hline \multirow[b]{2}{*}{ Characteristic } & \multicolumn{2}{|c|}{ Juvenile Sex Offenders (\%) } \\
\hline & $\begin{array}{c}\text { Female } \\
(N=979)\end{array}$ & $\begin{array}{c}\text { Male } \\
(N=12,450)\end{array}$ \\
\hline $\begin{array}{l}\text { Offender age (years) } \\
6-8 \\
9-11 \\
12-14 \\
15-17\end{array}$ & $\begin{array}{l}10.6 \\
20.6 \\
38.3 \\
30.4\end{array}$ & $\begin{array}{r}4.4 \\
10.0 \\
37.9 \\
47.7\end{array}$ \\
\hline $\begin{array}{l}\text { Multiple offenders in incident } \\
\text { Adult offender in incident } \\
\text { Multiple victims in incident }\end{array}$ & $\begin{array}{l}36.1 \\
12.6 \\
22.9\end{array}$ & $\begin{array}{r}22.9 \\
4.6 \\
12.0\end{array}$ \\
\hline $\begin{array}{l}\text { Victim identity (youngest victir } \\
\text { Family } \\
\text { Acquaintance } \\
\text { Stranger } \\
\text { Victim was also offender } \\
\text { Unknown }\end{array}$ & $\begin{array}{r}26.4 \\
57.0 \\
0.6 \\
6.3 \\
9.7\end{array}$ & $\begin{array}{r}24.9 \\
63.8 \\
2.6 \\
0.4 \\
8.3\end{array}$ \\
\hline $\begin{array}{l}\text { Incident location } \\
\text { Residence/home } \\
\text { School/college } \\
\text { Store/building } \\
\text { Outside } \\
\text { Other/unknown }\end{array}$ & $\begin{array}{r}77.2 \\
6.5 \\
4.8 \\
4.3 \\
7.2\end{array}$ & $\begin{array}{r}68.2 \\
12.4 \\
3.8 \\
7.3 \\
8.4\end{array}$ \\
\hline $\begin{array}{l}\text { Victim gender (youngest victim } \\
\text { Male } \\
\text { Female }\end{array}$ & $\begin{array}{l}36.6 \\
63.4\end{array}$ & $\begin{array}{l}21.4 \\
78.6\end{array}$ \\
\hline $\begin{array}{l}\text { Age of youngest victim (years) } \\
0-6 \\
7-10 \\
11-14 \\
15-17\end{array}$ & $\begin{array}{l}39.8 \\
20.2 \\
26.0 \\
13.9\end{array}$ & $\begin{array}{l}25.6 \\
17.8 \\
39.2 \\
17.4\end{array}$ \\
\hline $\begin{array}{l}\text { Type of sex offense } \\
\text { Forcible } \\
\text { Nonforcible }\end{array}$ & $\begin{array}{r}91.0 \\
9.0\end{array}$ & $\begin{array}{r}90.4 \\
9.6\end{array}$ \\
\hline $\begin{array}{l}\text { Injury in incident } \\
\text { None } \\
\text { Minor } \\
\text { Major }\end{array}$ & $\begin{array}{r}87.6 \\
11.5 \\
0.9\end{array}$ & $\begin{array}{r}87.0 \\
10.5 \\
2.5\end{array}$ \\
\hline $\begin{array}{l}\text { Incident time of day } \\
\text { Morning (6 a.m. to } 12 \text { p.m.) } \\
\text { Afternoon (12 p.m. to } 6 \text { p.m.) } \\
\text { Evening }(6 \text { p.m. to } 12 \text { a.m.) } \\
\text { Night (12 a.m. to } 6 \text { a.m.) }\end{array}$ & $\begin{array}{r}27.4 \\
41.5 \\
27.0 \\
4.0\end{array}$ & $\begin{array}{r}26.6 \\
43.1 \\
25.1 \\
5.2\end{array}$ \\
\hline Arrest in incident & 26.7 & 30.9 \\
\hline
\end{tabular}

Source: U.S. Department of Justice, Federal Bureau of Investigation, National Incident-Based Reporting System, 2004.

the possibility of sexual misbehavior at the hands of older boys. Adults should be equally vigilant in protecting young boys as in protecting young girls.

Another significant finding is that juvenile offenders are more likely than adult offenders to commit illegal sexual behavior in groups. This finding mirrors recent work in other countries that also has shown that juveniles commit more sex crimes in groups (Kjellgren et al., 2006). Although some of these group-involved juveniles may have offended on their own, the findings suggest that peer influences play as much of a role in juvenile sexual delinquency as they do in nonsexual delinquency, underscoring the need for prevention efforts to look beyond individual pathology and consider male adolescent peer cultures. It may be possible to devise interventions that would help inoculate some malleable, but less delinquency prone, youth to resist such peer influence. Such efforts could be extensions of some of the work in the field to promote more prosocial actions by "bystanders" with regard to date rape (Banyard, Moynihan, and Plante, 2007).

Data from police reports also show that, overall, older offenders tend to choose older victims. Juveniles who commit sexual offenses tend to do so against their age mates or somewhat younger children. In fact, offenses against young children actually decline across offender age, as offenders move from early to middle adolescence. This contradicts an assumption behind some sex offender treatment that a fixed attraction to young children (i.e., pedophilia) is the sole or even predominant motivation for juvenile sex offenses. The relationships between victim and offender age found in this study may suggest developmental hypotheses for the clinical assessment of juveniles. To the extent that epidemiologically rarer events correspond to greater individual deviancy, cases of older teenagers victimizing much younger children might raise relatively more concern and pose higher future risk than cases where younger teenagers victimize young children. Because it is more common for younger teenagers than older teenagers to engage in illegal sexual behavior with younger children, this scenario may reflect comparatively lower levels of individual pathology.

Juvenile sex offenders known to law enforcement appear to commit a greater number of group-involved cases and teenager-on-teenager cases than one might 
expect from studies of clinical populations in which a typical offender is a single teenager victimizing a younger child. Although the clinical literature on juvenile sex offenders has not emphasized teenager-on-teenager sexual assault, the NIBRS data suggest that this problem is very prevalent among middle- and late-adolescent males. It is possible that the juvenile justice system processes group-involved and teenager-on-teenager cases differently or that these offenders are less likely to receive services. How the system handles youth and how well current juvenile

\section{Table 4: Juvenile Sex Offenders as a Percentage of All Juvenile Violent Offenders, by Agency Size}

\begin{tabular}{lccr} 
& & \multicolumn{2}{c}{ Quartile (\%) } \\
\cline { 3 - 4 } Agency population * & Percent & Lower & Upper \\
\hline Less than 50,000 & 7.3 & 1.9 & 11.5 \\
$50,000-100,000$ & 6.3 & 3.2 & 9.5 \\
$100,000-300,000$ & 6.7 & 4.1 & 11.9 \\
More than 300,000 & 4.7 & 3.4 & 12.1
\end{tabular}

*Table includes only agencies classified by NIBRS as cities (population more than 5,000 ) and which reported at least 10 juvenile violent offenders ( $N=1,010$ agencies).

Source: U.S. Department of Justice, Federal Bureau of Investigation, National Incident-Based Reporting System, 2004.

\section{Figure 5: Juvenile Sex Offenders Versus Female Juvenile Victims}
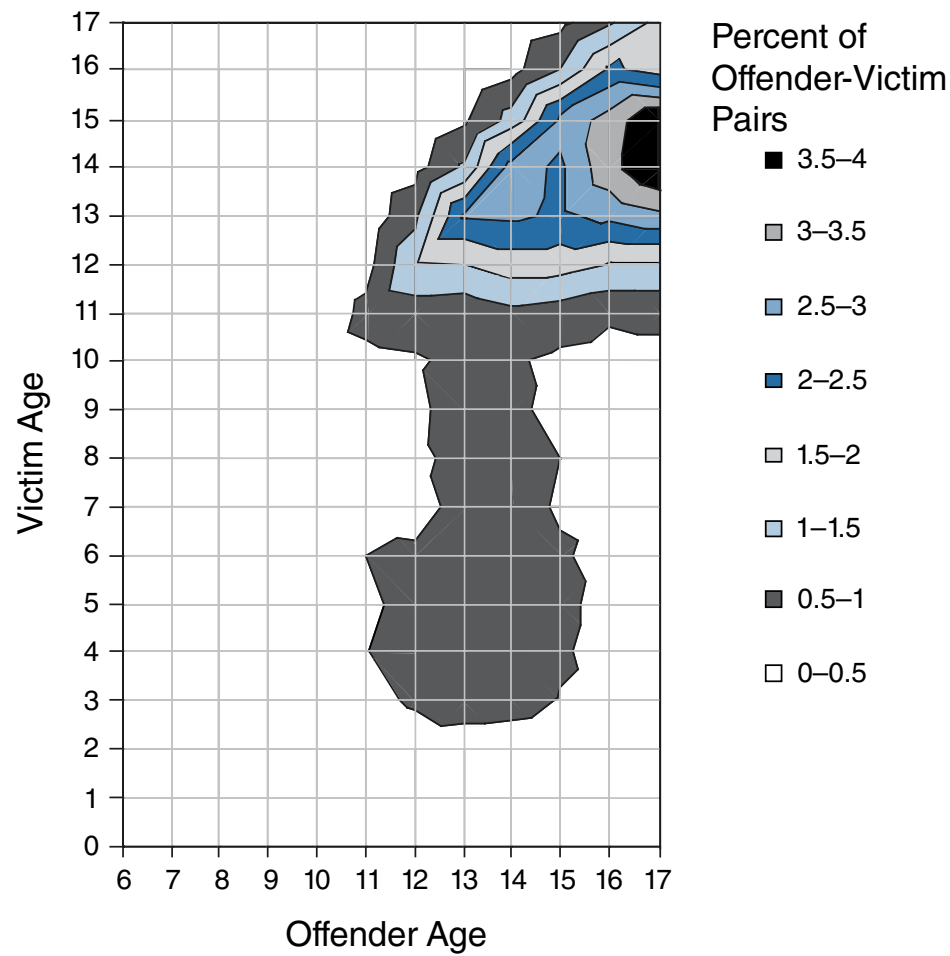

$\square 0-0.5$

Source: U.S. Department of Justice, Federal Bureau of Investigation, National Incident-Based Reporting System, 2004. justice programming addresses their needs may need further examination. Peer assaults and date rapes have sometimes received less attention than the sexual abuse of young children by teenagers. However, peer assaults and date rape may be easier to prevent because the power differential or developmental difference between offender and victim in these cases is less than that between a teenager and a much younger victim. Because juvenile sexual assaults are more likely than adult assaults to occur at school or during afterschool hours, efforts to prevent juvenile assaults might benefit from actions focused on these settings.

This analysis found considerable variation across jurisdictions and communities in the proportion of juvenile offenses that were sexual in nature. There are a number of possibilities, including real differences in prevalence rates, different rates of overall crime or crime reporting, or differential willingness to report or investigate juvenile sex offenses in particular, that might explain this finding. Observation suggests real variation in community approaches to juvenile sex offending. In some communities, officials handle juvenile sex offense cases more within the child protection system than within the criminal justice system. Exclusive handling of a case within the child welfare system may occur more often when a young child commits the offense or when the offense occurs within the family, possibly causing these types of cases to be underrepresented in NIBRS data.

If the variation is indeed due to differences in community practice, it may merit additional study, particularly to test whether more aggressive or more criminal-justiceoriented approaches to the problem have advantages over less aggressive approaches or ones that emphasize other institutions such as child protective services or mental health agencies. Some communities have clearly made this problem a law enforcement priority. Although there are many reasons to think that such a priority could have benefits for the community and victims and result in a reduction of sex offending, these are propositions that researchers must evaluate. On the other hand, questions have been raised about whether particularly harsh or stigmatizing community policies-for example placing juveniles on public sex offender registries or excluding these youth from normal social interactions-may have unintended negative consequences, such as deterring reporting, decreasing juvenile justice 
system involvement in cases, or hindering youths' prosocial developmental that may lead to increased crime risk (Letourneau and Armstrong, 2008).

\section{Conclusion}

The issue of juvenile sex offenses against minors, like most issues involving sex crimes and minors, will continue to attract considerable controversy and debate. Such debates can often continue unresolved or with questionable policy outcomes in the absence of good epidemiology and other research about the problem and its dynamics. The NIBRS dataset, which is growing to encompass an ever larger number of jurisdictions nationwide, is one resource that can help provide some empirical perspective and should continue to be analyzed for the insights it can offer.

\section{For Further Information}

This Bulletin presents information taken from the National Incident-Based Reporting System, 2004.

\section{References}

Alexander, M.A. 1999. Sexual offender treatment efficacy revisited. Sex Abuse 11(2):101-116.

Banyard, V.L., Moynihan, M.M., and Plante, E.G. 2007. Sexual violence prevention through bystander education: An experimental evaluation. Journal of Community Psychology 35: 463-481.

Becker, J.V. 1998. What we know about the characteristics and treatment of adolescents who have committed sexual offenses. Child Maltreatment 3:317-329.

Borduin, C.M., and Schaeffer, C.M. 2001. Multisystemic treatment of juvenile sexual offenders: A progress report. Journal of Psychology and Human Sexuality 13:25-42.

Caldwell, M.F. 2002. What we do not know about juvenile sexual reoffense risk. Child Maltreatment 7(4):291-302.

Carpentier, M., Silovsky, J.F., and Chaffin, M. 2006. Randomized trial of treatment for children with sexual behavior problems: Ten-year followup. Journal of Consulting and Clinical Psychology 74:482-488.

Center for Sex Offender Management. 1999. Understanding Juvenile Sexual Offending Behavior: Emerging Research, Treatment Approaches and Management Practices. Silver Spring, MD: Center for Effective Public Policy.
Centers for Disease Control and Prevention. 2004. Sexual Violence Prevention: Beginning the Dialogue. Atlanta, GA: Centers for Disease Control and Prevention. Retrieved March 25, 2009, from the Web: www.cdc.gov/NCIPC/dvp/ SVPrevention.htm.

Chaffin, M. 2005. Can we develop evidencebased practice for adolescent sex offenders? In Current Perspectives: Working With Sexually Aggressive Youth and Youth With Sexual Behavior Problems, edited by R.E. Longo and D. Prescott. Holyoke, MA: NEARI Press, pp. 119-141.

Chaffin, M., Berliner, L., Block, R., Johnson, T.C., Friedrich, W.N., Louis, D.G., Lyon, T.D., Page, I.J., Prescott, D.S., Silovsky, J.F. 2008. Report of the ATSA Task Force on Children With Sexual Behavior Problems. Child Maltreatment 13(2):199-218.

Chaffin, M., Letourneau, E., and Silovsky, J.F. 2002. Adults, adolescents, and children who sexually abuse children: A developmental perspective. In The APSAC Handbook on Child Maltreatment, 2nd ed., edited by J.E.B. Myers, L. Berliner, J. Briere, C.T. Hendrix, C. Jenny, and T.A. Reid. Thousand Oaks, CA: Sage Publications, pp. 205-232.

Davis, G.E., and Leitenberg, H. 1987. Adolescent sexual offenders. Psychological Bulletin 101:417-427.

Elliott, D.S., Huizinga, D., and Menard, S. 1989. Multiple Problem Youth: Delinquency, Substance Use, and Mental Health Problems. New York, NY: Springer-Verlag.

Hunter, J.A., Figueredo, A.J., Malamuth, N.M., and Becker, J.V. 2003. Juvenile sex offenders: Toward the development of a typology. Sexual Abuse: A Journal of Research and Treatment 15(1):27-48.

Kjellgren, C., Wassbert, A., Carlberg, M., Langstrom, N., and Svedin, C. 2006. Adolescent sexual offenders: A total survey of referrals to social services in Sweden and subgroup characteristics. Sexual Abuse: A Journal of Research and Treatment 18:357-372.

Knopp, F.H., Freeman-Longo, R., and Stevenson, W.F. 1992. Nationwide Survey of Juvenile and Adult Sex-Offender Treatment Programs and Models. Orwell, VT: The Safer Society Press.

Lambie, I., Seymour, F., Lee, A., and Adams, P. 2002. Resiliency in the victim-offender cycle in male sexual abuse. Sexual Abuse: A Journal of Research and Treatment 14(1):31-48.

Letourneau, E.J., and Armstrong, K.S. 2008. Recidivism rates for registered and nonregistered juvenile sexual offenders. Sexual Abuse: Journal of Research and Treatment 20(4):393-408.
Letourneau, E.J., Henggeler, S.W., Borduin, C.M., Schewe, P.A., McCart, M.R., Chapman, J.E., and Saldana, L. 2009. Multisystemic therapy for juvenile sexual offenders: 1-year results from a randomized effectiveness trial. Journal of Family Psychology 23(1):89-102.

Letourneau, E.J., and Miner, M.H. 2005. Juvenile sex offenders: A case against the legal and clinical status quo. Sexual Abuse: A Journal of Research and Treatment 17(3):293-312.

Parks, G., and Bard, D. 2006. Risk factors for adolescent sex offender recidivism: Evaluation of predictive factors and comparison of three groups based upon victim type. Sexual Abuse: A Journal of Research and Treatment 18(4): 319-342.

Reitzel, L.R., and Carbonell, J.L. 2007. The effectiveness of sexual offender treatment for juveniles as measured by recidivism: A metaanalysis. Sexual Abuse: A Journal of Research and Treatment 18:401-422.

Righthand, S., Prentky, R., Knight, R., Carpenter, E., Hecker, J.E., and Nangle, D. 2005. Factor structure and validation of the Juvenile Sex Offenders Assessment Protocol (J-SOAP). Sexual Abuse: A Journal of Research and Treatment 17(1):13-30.

Ryan, G.D. 1997. Perpetration prevention: Primary and secondary. In Juvenile Sexual Offending: Causes, Consequences and Correction, edited by G.D. Ryan and S.L. Lane. San Francisco, CA: Jossey-Bass, pp. 433-454.

Silovsky, J.F., and Niec, L. 2002. Characteristics of young children with sexual behavior problems: A pilot study. Child Maltreatment 7:187-197.

Snyder, H.N., and Sickmund, M. 1999. Juvenile Offenders and Victims: 1999 National Report. Washington, DC: U.S. Department of Justice, Office of Justice Programs, Office of Juvenile Justice and Delinquency Prevention.

U.S. Department of Justice, Federal Bureau of Investigation. 2004. National Incident-Based Reporting System, 2004. Compiled by the U.S. Department of Justice, Federal Bureau of Investigation. ICPSR04468-v1. Ann Arbor, MI: Inter-university Consortium for Political and Social Research, 2006-09-20. doi:10.3886/ICPSR04468.

Widom, C.S., and Ames, M.A. 1994. Criminal consequences of childhood sexual victimization. Child Abuse and Neglect 18(4):303-318.

Worling, J.R. 2004. The estimate of risk of adolescent sexual offense recidivism (ERASOR): Preliminary psychometric data. Sexual Abuse: A Journal of Research and Treatment 16(3):235-254. 
Washington, DC 20531

Official Business

Penalty for Private Use $\$ 300$

\section{Acknowledgments}

This Bulletin was prepared by David Finkelhor, Ph.D., professor of sociology and director, Crimes against Children Research Center, University of New Hampshire, Durham, NH; Richard Ormrod, Ph.D., research professor, Crimes against Children Research Center, University of New Hampshire, Durham, NH; and Mark Chaffin, Ph.D., professor of pediatrics, University of Oklahoma Health Sciences Center, Oklahoma City, OK.

\section{Share With Your Colleagues}

Unless otherwise noted, OJJDP publications are not copyright protected. We encourage you to reproduce this document, share it with your colleagues, and reprint it in your newsletter or journal. However, if you reprint, please cite OJJDP and the authors of this Bulletin. We are also interested in your feedback, such as how you received a copy, how you intend to use the information, and how OJJDP materials meet your individual or agency needs. Please direct your comments and questions to:

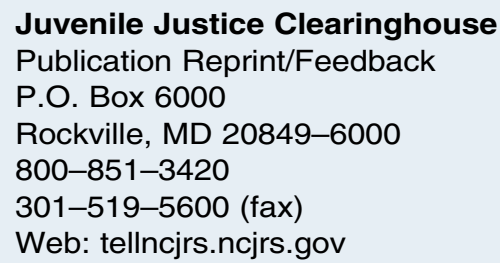

This Bulletin was prepared under cooperative agreement number 2005-JL-FX-0048 from the Office of Juvenile Justice and Delinquency Prevention (OJJDP), U.S. Department of Justice.

Points of view or opinions expressed in this document are those of the authors and do not necessarily represent the official position or policies of OJJDP or the U.S. Department of Justice.

The Office of Juvenile Justice and Delinquency Prevention is a component of the Office of Justice Programs, which also includes the Bureau of Justice Assistance; the Bureau of Justice Statistics; the Community Capacity Development Office; the National Institute of Justice; the Office for Victims of Crime; and the Office of Sex Offender Sentencing, Monitoring, Apprehending, Registering, and Tracking (SMART). 